\title{
Acting Styles, Nuances and Linguistic Aesthetics: A Case Study of Ibrahim Chattah in Yoruba Films.
}

\author{
Adejoke Adetoun Fadirepo and Adeyemi Oluwadamilare Oresanya \\ Department of Performing Arts \\ Olabisi Onabanjo University \\ Ago-Iwoye, Nigeria \\ jokemuyiwa@hotmail.com; adeyemioresanya@gmail.com
}

\begin{abstract}
Acting style is the artistic feature and ingenuity of the actor exhibited over a long period of time acting in films. It is the attainment and acquisition of skills, ingenious and professional creativity, exhibited by the actor in the process of carrying out a role in film or play production. Acting style can be inferred to be individualistic. In Yoruba films, there is a crop of non-native actors who are fluent in the language of their nativity as well as being conversational in the Yoruba language movies which aid their celebrity status. The inability to acculturate to the expected character through diction, gesticulation and socio-linguistic nuances create disorientation between the actors and the audience. This study is hinged on Whorpian Theory on language which posits that the individual perceives his or her environment through the process of thought which is influenced by the language he uses. The method of research is content analytical. Film content is analyzed to raise awareness on the style, nuances linguistic aesthetics of Ibrahim Chattah in selected films. Our findings show that producers and casting directors are the culprit of this deficiency, due to their sense of profit making by using casts with celebrity status in order to increase their profit margin at the show room. This study thereby concludes that directors, producers and casting directors should be more creative by developing a sense of professionalism, making preference for quality over quantity in the Yoruba films. This research recommends adequate training for all actors, especially multilingual ones to increase their
\end{abstract}


versatility, develop skill and technique in order to sustain them and increase their market value in the industry.

Keywords: Acting Style, Ibrahim Chatta, Nuances, and Linguistic Aesthetics

\section{Introduction}

Acting style has no particular definition, it can be considered a phenomenon in an actor, it can also be deployed to use through intuition and immediate reasoning. The style of an actor in performance can also be described as part of his talent. Talent is a divine gift that can be used in numerous ways positively, but if not developed properly, it becomes a waste of resources. According to Bowskill as noted in Sola Fosudo (2017), "[a]cting and living have much in common". This can be inferred to mean that no matter how much an actor distance himself/herself from a role played in film or on stage, there is still a possibility of an atom of the individual's personality attached to such roles. This is because an actor is first a living soul with emotional attachment before taking up the acting profession. An actor's acting style should not be misconstrued as mere impersonation or pretension but to be seen as a virtuous and committed means to exploit a role effectively and efficiently in order to convince the audience.

For an actor to be known with a definite style, such actor must have been able to master the much need skills and technique through constant practice. Plausibility and impact are the keywords synonymous with acting style; hence style is the learned technique of the actor to make his acting authentic. The actor's ability to synthesize emotion with language and diction of the required period and setting is an indication of his versatility, professionalism and discipline, which are imbibed through training and consistent practice. This was corroborated by Cohen that "the art of acting, it is often maintained, is the actor's ability to essay a wide range of roles of varying ages, historical periods, dramatic characteristics and styles". The underplay of nativity in the Yoruba indigenous setting by non native Yoruba actors is the concern of this study, in as much as they are partly to blame for not been versatile enough to scale through the hurdle of hybridity in dramatic expression, in a profession that is expected to provide sustainability, and the marketers who demand for them because of their celebrity status, the audience is bound to underrate the actor and this also can lead such actor to the poverty margin. For the actor, education is important to scale through this hurdle, as he or she is exposed to the theory and practice, including sustainability to ensure continuous practice. This work exposes the acting styles, nuances and linguistic aesthetics in 
Nigeria's Nollywood Yoruba film industry using Ibrahim Chatta as the potential paradigm.

\section{Acting Styles through the Ages}

Acting style is the artistic feature and ingenuity of the actor exhibited over a long period of time acting in films. It is the attainment and acquisition of skills, ingenious and professional creativity, exhibited by the actor in the process of carrying out a role in film or play production. Over time acting style becomes the actor's unique way of expressing emotions and generally, easiest means of role playing in films. This however means that concrete knowledge of a role in the play, series or film gives an actor the opportunity to various strategies in achieving the objectives required of the role. "Acting is neither 'being' nor 'feeling', though it may include both: it is a series of appropriate practices or processes in response to a text, or other starting point; it is different masks for different tasks. Harrop (1992) noted that actor's style is what makes possible both permutations upon a role, and the variations of style. Education on style for the actor cannot be overemphasized. A film production requires a dominant character who determines the success of the work of all other production crew. That dominant character is 'The actor'. She/he reflects as all artist do, the values, confidence, nuances and fashions of the society in which they perform. As a dramatic art form, acting through style also reflects changes in the society, moods tastes and clichés. Acting style can be inferred to be individualistic. It is a personal trait, opinionated characteristics and persona developed by an actor to suite a role either on stage or film production.

Classical acting styles was known for their broad gestures and declamatory speeches while Renaissance opted for the "inside out approach" which is a technical and natural flow of speech rendition. The target is on the psychological level of characterization. During the Restoration period, just like the name implies, the classical ideals of broad gesture, declamatory speech was restored. The nineteen century modernist approach to acting tilts towards "excessive emotional display". In the $20^{\text {th }}$ century, Constantine Stanislavsky revolutionized acting styles with the merge of the physical and the psychological level of characterization, forging the "inside out" and the "outside in" approach into what he called "a system" instead of a "theory" focusing on actor's working on self and working on the role. Referred to as "the father of modern acting" by various scholars, Brocket noted that Stanislavsky's system gained much acceptance because the method of acting was hinged on realism, which was the bane of artistic consciousness of the modernist dramaturgy.

There are various theories on acting styles, but the forerunner of style is believed to be Constantine Stanislavsky. Other theorists seemingly devised 
their own styles and methods of acting from Stanislavski's theory. One of Stanislavsky's styles is the concept of "Emotional Memory", a technique that stimulates the actor's personal experience, juxtaposes it into the similar emotions as their character. Ademuyiwa (2018) reiterated that "emotional memory is a technique of physicalizing the past emotions of the actor in the circumstances of the character'. Emotional authenticity is the keyword, past emotion is the motivation. Similar technique is created by Lee Strasberg which he names "substitution", a technique that allows the actor to substitute the emotions of the character to a personal experience as the name implies. Stanford Meiner uses "emotional preparedness", using improvisation to bring about realistic emotions. Stella Adler prefers "actor's imagination" to broaden their artistic scope and personal experiences to interpret their character.

Nollywood Yoruba films on the other hand refers to a socio-linguistic and cultural representation of the Yoruba in films of the dramatic expression. Ademuyiwa (2018) described Nollywood as "the face of Nigeria in the eye of the video camera while Adebanjo (2011) noted that Nollywood to be the Nigerian film culture. Acting style in this industry is dependent on the individual actor to execute. Though not theorized but plausible, many actors follow the Stanislavski's "the system" and other theories discussed above. For the film and acting culture in Nollywood, style is also culture bound; it is also anchored on the actor's emotional needs, temperament and the needs of the character in the setting of the play.

Uncontrovertibly, actors, through the art of acting, are prominent and important stakeholders in the business and affairs of showcasing linguistic and cultural identity of a society, through concrete and non-concrete measures, dramatic elements of language, either colloquial or modern, stylistic, theme, characterization, diction, through costume, make up, songs and so on. There are two categories of actors in Nollywood Yoruba, also known as Yoruba actors, or actors who make use of Yoruba as a language of expression. They are the non elite and the elite actors. The non elite are the veterans, who are the diehard professional actors, who started with the late Hubert Ogunde, the theatre icon, considered to be the father of modern contemporary Nigerian theatre. They are the likes of Baba Wande, (Kareem Adepoju), Eda Onile Ola (Lere Paimo), Tubosun Odunsi, (Paadi Mukailu), Baba Sala, Aderupoko, Fokoko, (Oga Bello) Olofa 'na, Gbolagade Akinpelu, Sokoti and a few others. The elite are comprised of the educated actors, who are versed in Yoruba and English language, and who by circumstances have travelled beyond their land of nativity, thereby exposed to other ethnic language and cultural affinities. Some of them are Femi Adebayo, Tope Adebayo, Bolanle Ninalowo, Odun Adekola, Funso Adeolu, Yomi Fash-Lanso, Ibrahim Chattah and a host of others. Unfortunately, most of the elite actors lack the versatility in terms of 
language and diction to code switch in between the Yoruba indigenous cultured movie which is the focus of analysis of this study and the modern contemporary drama in terms of diction and characterization.

\section{Linguistic Interference}

The obvious problem of the above mentioned elite actors is linguistic interference which is also known as cross linguistic influence in Yoruba cultured films. From Ademuyiwa's (2018) observation, "these actors do not measure up to the level of plausibility due to the socio-linguistic nativity crisis especially in traditional films." Interference occurs when the actor fails to have a native level command of a language as when translating to a second language, hence in perceiving and performing, old habits tend to intrude and interfere.

\section{Language, Acting and Communication.}

Language is a vital expression of culture and identity. Nollywood Yoruba is a face of the Yoruba culture, language and philosophy to process and express thought and ideals of the past, the present and the future. This is succinctly expressed by Ademuyiwa (2018) thus "Language is a means of communication and its function to the expression of culture is invaluable as it is an essential part of culture to communicate values, beliefs and customs, it has an important social function and also fosters feelings of group identity and solidarity". From the above articulation on language, it is important to know that the success of believable acting either on stage, screen and radio is holistically anchored on language and speech in the required language for effective communication. Failure in communication leads to defective acting and sustainability in the career.

From observation, non Yoruba native actors are obviously defective in their Yoruba diction, leading to defective characterization, due to the problem of their own language of nativity, which interferes in the additive meaning construed to certain words in Yoruba language. Language has a strong bearing with nativity; hence the role-play of nativity is the gamble of characterization. Ademuyiwa (2018) noted that "A defective characterization disorientates the viewer and this result in the actor losing credibility and aesthetic value, a non-Yoruba native actor who is cast in a Yoruba traditional role may be defective in his expression since he is not learned in the indigenous or colloquial native language."

The Whorpian hypothesis on language: Lee Whorf opines that the individual perception of his environment is determined by the thought process which ultimately is influenced by the language he uses. Whorf explains further that there is connectivity between how different cultures perceive their 
world and the way language is used. (Young 1998). This is evident in the act of these actors whose language of nativity intercept and corrodes the linguistic interpretation of their roles.

\section{Acting Style of Ibrahim Chattah}

Ibrahim Chattah is one of the fast rising actors in the Nollywood Yoruba, this versatile actor has gone a long way to create a niche for excellence in the art of role play. Ibrahim Chattah cannot be labeled elite in the real sense of the word as he confessed that he did not complete his secondary school education, but his achievement drives home the point that education is not limited to the four walls of a classroom. His skill of role interpretation among his peers is almost unequalled. He is endowed with almost everything an actor needs: confidence, boldness, concentration, technique, body memory, sharp usage of his five senses, above all, humility.

In a short interview with this researcher, Chattah reveals that he was born of a Tapa father, and a Yoruba mother. Nupe is a tribe in Kwara state of Nigeria and the language is Tapa. He claims Yoruba as his first language, Tapa as his native but second language. This is due to the fact that he was born in Bacita, a commercial center in Nupeland, and a notable sugar production factory town in Kwara state. Bacita was founded and consolidated by several ethnic groups namely Yoruba, Tiv, Ibo, Hausa, Igbira including Fulani traders mainly because of its economic viability. He bears the name of his home town, Chattah, also situated in Etu local government area and a minority group in Lafiaji, also in Nupeland, Kwara state. The multiplicity of language in Bacita made it a centre of attraction for the earlier theatre practitioners to travel there for performances especially for the Yoruba audience. Chattah was inspired by the likes of Ray Eyiwunmi, a notable member of Duro Ladipo travelling theatre in the $70 \mathrm{~s}$ and $80 \mathrm{~s}$, and whom he regarded as a role model in the skill of role interpretation, traditional chants, praise songs, incantations and Bata drums. Another major influence was his mother's egúngún lineage from Modakeke town in Osun state of Nigeria. The masquerades dance with the bàtá drums and chants accompaniment were forces of inspiration, hence his near perfect skill of role interpretation in the indigenized Yoruba movies. This prolific actor can interpreted both modern and cultural movies plausibly.

Some of his movies include: Àdìún Olóríodò, Aṣo Oge, Àkàlàmàgbò, İyàwó Adédigba to mention but a few. When asked about his theatre training, Chattah reveals that he did not train under anybody neither did he attend any theatre or film school. As a lover of dramatic arts, he is passionate about acting in films. He is also very observant and informally studious, even though he subscribes to training and skill acquisition for creativity and excellence. 
He also studied some international actors, some of which are Nel Gibson, Idris Elba, Russel Crow, Nicholas Cage, and Al Pacino. He also loves Amitab Bachchan, Shirak Khan, and Hrithic Roshan.

\section{The Film Àkàlàmàgbò}

The film centers on the Yoruba ancient fable which depicts a sensible side to magnanimity. The Horn bird àkàlàmàgbò is believed to develop a protuberance on its neck due to kindness shown to rescue a snake from its pursuers. A hunter swallows the snake, when the coast becomes clear, the snake refuses to be emitted from the hunter's stomach, and instead it fancies the hunter's internal organs other than the food it scavenges in the bush. The hornbill attempts to draw the snake from the hunter's stomach, but out of frustration, as the hornbill's beak draws the snake out, the hunter gives a punch to the neck of the hornbill in order to hasten the emission of the snake, hence the hornbill develops a protuberance. The ancient fable is characterized into the story of the film. The demise of kings of a community shortly after coronation necessitates a community to invite a particular dynasty, chosen by the oracle to cast off this spell. Ably represented by Adetoyese and his junior brother, Oyediran. The senior brother affectionately concurs to the choice of his junior brother to be king so as to be able to run around for him in case of trouble. The junior brother becomes power drunk and in order to punish his cousin, Adetoyese's only child, Oyediran orders him to be beheaded, and this leads to a can of worms.

\section{Characterization and Linguistic Aesthetics by Ibrahim Chattah}

Unlike few other actors in Yoruba cultured movies, whose language of nativity differs from the expected Yoruba colloquial diction, Chattah's style of cultural and linguistic interpretation as King Oyediran in the film, àkàlàmàgbò is exemplary. Being a man from Nupe land, even though Yoruba is his first language, he is not only conversational in the dialect; he is also deeply rooted in the colloquial diction and clichés. It is worthy of note that Chattah speaks Yoruba, Tapa and English language fluently and not conversationally. Despite his multi-linguistic talent, he displays no traceable accent of other languages in his Yoruba diction. This epic achievement is possible because of his background, his involvement in his maternal lineage, the bata drums, his passion, and his resilience. Despite his minimum education, his perseverance as an actor, his studious nature, all these enable him to rise to stardom, having developed his skill and style of role interpretation by self effort, and observation of other local and international actors. 


\section{Conclusion}

Multilingual actors in Nollywood Yoruba, either elitist or none, have a problem with cultural and linguistic interpretation of roles in Yoruba indigenous films. This is evident in their roles which makes their acting defective due to linguistic interference from their language of nativity. This interference consequently inhibits their flow of language delivery, nuances and mood. The Whorpian hypothesis observes that the individual perception of his world is reflective in the use of language, hence polyglots' actors can be limited in the socio-linguistic representation of their role which demands a deep rooted indigenous characterization, diction and language. This inability to acculturate becomes an obstacle to creativity. Ibrahim Chattah may not be able to communicate his acting style, but in the real sense, watching him perform, one is likely to be awe struck as he combines all styles: Stanislavski's "the system", Lee Strasberg "substitution", Stela Adler's "emotional preparedness". His eclectic acting style has over the years singled him out as a very good and versatile actor, who can act any role, near perfectly and professionally.

Actors are story tellers who must be ready to learn, imbibe and be acquainted with skills and technique for sustainability. This can be possible through training, rehearsals and experimentation in performances. Producers and casting directors need to think beyond the profit margin by casting actors who they believe are sell points in the cinema. There are critical and uncritical audience who cannot trade quantity with quality films and who demand for money's worth. Creativity should not be compromised.

\section{Bibliography}

Ademuyiwa, A. Underplaying the Native: A study of Personal Styles, Nuances of Polyglot Actors In Yoruba Nollywood Films (Unpublished Ph.D. Thesis) 35 (2018).

Adebanjo, N. Cultural Studies: Theories, Concept and Practice. Yerima \& Obafemi (eds). National Institute, Kuru, Plateau State, Nigeria, 173 (2011). Brocket, O. History of the Theatre: Allynand Bacon, 421 (1999).

Cohen, R. Acting Professionally: Raw Facts about careers in Acting. Mayfield Publishing Company. University of California, Irvine, 17 (1981).

Fosudo, S. The Art of Acting: The Necessity of Training for Technique. Ilorin: The Department Of Performing. African Theatre: Studies in Theory and Criticism. Kofoworola, Zikky et al. 254(2017)

Harrop, J. Acting: The dynamics of acting: style. London: Routledge, 73 (1992). 


\section{Videography}

Ifá İwà produced by Abdulateef Titilope (2014).

Asṣà produced by Fathia Balogun Williams (2017).

Àkàlàmàgbò, produced by Tunde Ola Yusuf (2017). 
